\title{
БИОКЛИМАТИЧЕСКИЕ И ЭКОЛОГО- ГЕОГРАФИЧЕСКИЕ ОСОБЕННОСТИ АДВЕНТИВНЫХ ВИДОВ ЮГА РОССИЙСКОГО ПРИЧЕРНОМОРЬЯ
}

\section{А.В. Егошин}

Экологический образовательный и научный центр ФГБУ «Сочинский национальный парк», Сочи, Россия

Эл.nочma: ecoid@ya.ru

Статья поступила в редакиию 01.10.2014; принята к печати 11.11.2014

Проанализирован видовой состав адвентивной флоры юга Российского Причерноморья. Установлены закономерности пространственного распределения чужеродных видов, а также их биоклиматические и эколого-географические особенности. Большинство исследуемых адвентивных видов, натурализовавшихся на юге Российского Причерноморья, исторически приурочено к биому листопадных лесов умеренного пояса. Биоклиматические условия юга Российского Причерноморья вплоть до среднегорья удовлетворяют требованиям подавляющего числа иноземных видов, что создает предпосылки для дальнейшего распространения этих видов в ходе хозяйственного освоения территории. Установлено, что в будущем климатические условия на юге Российского Причерноморья станут еще более комфортными для распространения большинства представителей исследуемых иноземных видов.

Ключевые слова: адвентивные виды, инвазии, ГИС, Российское Причерноморье.

\section{BIOCLIMATIC AND ECOGEOGRAPHIC CHARACTERISTICS OF ADVENTIVE SPECIES OF THE SOUTHERN PART OF RUSSIAN BLACK SEA COAST AREA \\ A.V. Yegoshin \\ Ecological Education and Research Center of Sochi National Park, Sochi, Russia E-mail: ecoid@ya.ru}

The composition of the adventive flora of the southern part of Russian Black Sea coast area has been analysed to define the spatial distribution of foreign species and their bioclimatic and ecogeographic features. Most adventive species found in this area are referred to deciduous broadleaf forests of the temperate zone. The bioclimatic conditions of the area up to its mid-highland are favorable for most of the foreign species and for their further spread associated with the economic development of these territories. The data suggest that future climatic conditions in the area will be even more favorable for the spread of most of the foreign species.

Keywords: adventive flora, invasion, GIS, Russian Black Sea cost area.

\section{Введение}

Натурализация адвентивных видов представляет большую угрозу биоразнообразию на всех уровнях организации (генетическом, видовом, экосистемном). Поэтому уделяется большое внимание выяснению причин, способствующих успешной натурализации адвентиков.

Активное распространение адвентивных видов в различных регионах связано, прежде всего, с их конкурентными преимуществами перед аборигенными видами [4]. Многие адвентики на своей родине являются видами начальных стадий сукцессий [24]. Не последнюю роль в успешной натурализации адвентиков играет и видовое разнообразие экосистемыакцептора $[11,14,20,22]$. Экосистемы, отличающиеся высоким видовым богатством, как правило, имеют и высокий уровень доминирования $[1,3]$, что затрудняет натурализацию иноземных видов.

Подавляющее большинство авторов [16, 21, 23, 25] придерживается мнения, что основным индуктором адвентизации является антропогенное воздействие на природные экосистемы. Антропогенная деятельность, приводящая к фрагментации местообитаний, способствует проникновению адвентивных видов в естественные экосистемы $[12,13,18]$. У «здоровой», не нарушенной экосистемы, как правило, имеются защитные механизмы, предотвращающие внедрение иноземных видов [15]. Поэтому не вызывает сомнений то, что количество натурализовавшихся адвентивных видов коррелирует с плотностью населения $[17,19,26]$.

Успешность натурализации иноземных видов во многом зависит и от разнообразия природно-климатических условий новой родины $[2,6]$. В Российской Федерации наиболее разнообразные природно-климатические условия (рельеф, почвы, климат) свойственны югу Российского Причерноморья, что способствует интенсивному развитию инвазионных процессов в этом регионе. В связи с этим актуальность приобретает моделирование пространственного распределения адвентивных видов, включая установление их биоклиматических и эколого-географических требований, что в итоге позволит оценить потенциальную подверженность инвазиям у экосистем, которым угрожает вмешательство человека.

\section{Материал и методика}

Геоинформационные технологии открывают широкие возможности для инвазионной биологии. Они позволяют установить биоклиматические и эколо- 
го-географические требования адвентивных видов, определить пригодность территории для произрастания этих видов, а также спрогнозировать их ответную реакцию на климатические изменения.

Для этого лишь необходимы соответствующие растровые картографические материалы, в каждой ячейке растра которых содержится информация о каком-либо параметре окружающей среды, а также географические координаты местонахождения особей изучаемых объектов живой природы.

В ходе полевых исследований, проведенных в 2012 и 2013 гг. на территории Большого Сочи, нами были зафиксированы географические координаты мест произрастаний особей наиболее распространенных адвентивных видов растений. Эти данные были дополнены географическими координатами мест произрастания чужеродных видов, представленными на сайте глобального информационного фонда по биоразнообразию (www.gbif.org). Для последующего анализа географические координаты мест произрастания адвентивных видов импортировали в среду программного комплекса ArcGIS. В результате была составлена база данных, содержащая географические координаты около двух миллионов мест произрастаний особей исследуемых видов по всему миру. Эти данные о пространственном распределении изучаемых видов легли в основу определения их биоклиматических и эколого-географических требований.

Для этого использовали биоклиматические переменные BIOCLIM, представленные набором растровых изображений (GRID) с разрешением около 1 км², каждая ячейка которых содержит информацию о различных климатических показателях (табл. 1).

Растровые слои с биоклиматическими переменными дополнили слоями, содержащими другую эколого-географическую информацию: высоту над уровнем моря, уклон в градусах, экспозицию, степень застроенности территории, глубину снежного покрова, вегетационный потенциал, чистую первичную продуктивность, сумму температур вегетацион- ного периода, влажность почвы, а также содержание в ней органического углерода.

Далее с помощью инструментария ArcGIS извлекали из растровых слоев значения эколого-географических и биоклиматических переменных в каждой точке произрастания особей изучаемых видов.

Полученные данные использовали для вычисления, минимальных, максимальных средних и медианных значений, а также изменчивости биоклиматических и эколого-географических характеристик мест произрастания особей адвентивных видов. Кластерный анализ проводили с использованием методов Варда и К-средних.

Для определения территории потенциально пригодной для произрастания чужеродных видов использовали программу MaxEnt (http:/www. cs.princeton.edu/ schapire/maxent/), которая широко применяется для моделирования пространственного распределения особей биологических видов методом максимальной энтропии. Используя растровые слои BIOCLIM и географические координаты мест произрастания изучаемых видов, MaxEnt позволяет рассчитать вероятность того, что биоклиматические условия определенной территории будут удовлетворять биологическим требованиям вида. Результаты работы программы могут быть представлены в виде растровой карты, каждая ячейка которой (в нашем

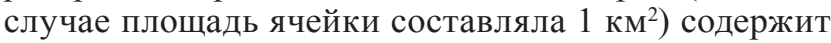
вероятностную оценку пригодности биоклиматических условий местности требованиям вида. Для того чтобы дать конкретный ответ на вопрос, пригодна ли конкретная территория для произрастания изучаемого вида, мы провели дискретную классификацию полученного растра. Для этого в качестве порогового значения использовали 10-й процентиль. Значения ниже 10-го процентиля считали как неудовлетворяющие экологическим требованиям вида.

Для оценки того, как климатические изменения повлияют на пространственное распределение адвентивных видов в будущем (2050 и 2070 гг.), также ис-

Биоклиматические переменные BIOCLIM

\begin{tabular}{|c|c|}
\hline Код & Биоклиматический параметр \\
\hline $\mathrm{BIO} 1$ & Средняя годовая температура \\
\hline $\mathrm{BIO} 2$ & Средняя суточная амплитуда температуры за каждый месяц \\
\hline $\mathrm{BIO} 3$ & Изотермичность $(\mathrm{BIO} 1 / \mathrm{BIO} 7) \times 100$ \\
\hline $\mathrm{BIO} 4$ & Стандартное отклонение температур \\
\hline $\mathrm{BIO} 5$ & Максимальная температура самого теплого месяца года \\
\hline $\mathrm{BIO6}$ & Минимальная температура самого холодного месяца года \\
\hline $\mathrm{BIO} 7$ & Годовая амплитуда температуры (BIO5-BIO6) \\
\hline $\mathrm{BIO} 8$ & Средняя температура самой влажной четверти года \\
\hline BIO9 & Средняя температура самой сухой четверти года \\
\hline $\mathrm{BIO} 10$ & Средняя температура самой теплой четверти года \\
\hline BIO11 & Средняя температура самой холодной четверти года \\
\hline $\mathrm{BIO} 12$ & Годовая сумма осадков \\
\hline $\mathrm{BIO} 13$ & Сумма осадков в самом влажном месяце года \\
\hline $\mathrm{BIO} 14$ & Сумма осадков в самом сухом месяце года \\
\hline $\mathrm{BIO} 15$ & Коэффициент вариации осадков \\
\hline BIO16 & Сумма осадков во влажной четверти года \\
\hline BIO17 & Сумма осадков в сухой четверти года \\
\hline $\mathrm{BIO} 18$ & Сумма осадков в самой теплой четверти года \\
\hline BIO19 & Сумма осадков в самой холодной четверти года \\
\hline
\end{tabular}


пользовали растровые слои BIOCLIM, рассчитанные с использованием климатической модели CCSM4 для четырех репрезентативных траекторий концентраций (RCP), которые были разработаны Межправительственной группой по изменению климата (IPCC). RCP являются сценариями климатических состояний, характеризующими величину антропогенно обусловленного радиационного воздействия, достигаемого к 2100 г. по сравнению с 1750 г. (2,6; 4,$5 ; 6,0$ и 8,5 Вт/м²). Согласно этим сценариям, вероятные оценки увеличения глобальной температуры к концу 2100 г. составят: $0,2-1,8{ }^{\circ} \mathrm{C}$ (RCP2.6); $1,0-2,6^{\circ} \mathrm{C}$ (RCP4.5); 1,3-3, ${ }^{\circ} \mathrm{C}$ (RCP6.0); 2,6-4,8 ${ }^{\circ} \mathrm{C}$ (RCP8.5) [5].

\section{Результаты и их обсуждение}

Адвентивный компонент флоры Российского Причерноморья изучен достаточно хорошо [4, 7-9, 10]. Многие заносные виды, упоминаемые в вышеперечисленных работах, не способны натурализоваться даже в нарушенных экосистемах. Поэтому на первом этапе нами были выделены виды растений, особи которых способны проникать в нарушенные и слабонарушенные экосистемы юга Российского Причерноморья.

На основании проведенных полевых исследований все адвентивные виды юга Российского Причерноморья нами были разделены на 5 классов инвазионной валентности: 1 - виды, не образующие самоподдерживающихся популяций, которые без постоянного притока генетического материала, как правило, быстро угасают; 2 - виды, формирующие популяции, которые обладают способностью к самоподдержанию в течение определенного периода времени, не внедряясь в природные экосистемы; 3 - виды, распространяющиеся в антропогенно нарушенных экосистемах (линии электропередач, дороги и т. д.); 4 - виды, вне- дряющиеся в естественно нарушенные природные экосистемы (вывалы деревьев, берега горных рек); 5) виды, способные проникать в ненарушенные природные экосистемы.

Анализ флоры показал, что общее количество адвентивных видов на юге Российского Причерноморья, принадлежащих к классам 2-5 инвазионной валентности, составляет 283. Эти виды принадлежат к 68 семействам. Наиболее многочисленны иноземные виды семейств Poaceae (42 вида) и Asteraceae (37 видов).

Родиной большинства адвентивных видов, натурализовавшихся на юге Российского Причерноморья, являются Северная и Центральная Америка (88 видов), а также Юго-Восточная Азия и Япония (74 вида).

К наиболее агрессивным адвентикам, принадлежащим к 4-5 классам инвазионной валентности, может быть причислено не более 30 видов. Тем не менее, во многих слабонарушенных экосистемах эти виды могут достигать высокого уровня обилия. По-видимому, интенсивное внедрение этих видов в ненарушенные и слабонарушенные экосистемы юга Российского Причерноморья отчасти связано с их естественной неполночленностью, возникшей в результате плейстоценовых оледенений.

Прогностическое моделирование с использованием программы MaxEnt показало, что биоклиматические условия юга Российского Причерноморья, вплоть до среднегорья, удовлетворяют требованиям подавляющего большинства адвентивных видов, принадлежащих к 3-5 классам инвазионной валентности. На рис. 1 представлены результаты моделирования и дискретной классификации растра, иллюстрирующие пригодность биоклиматических условий юга Российского Причерноморья для произрастания айланта высочайшего (Ailanthus altissima).

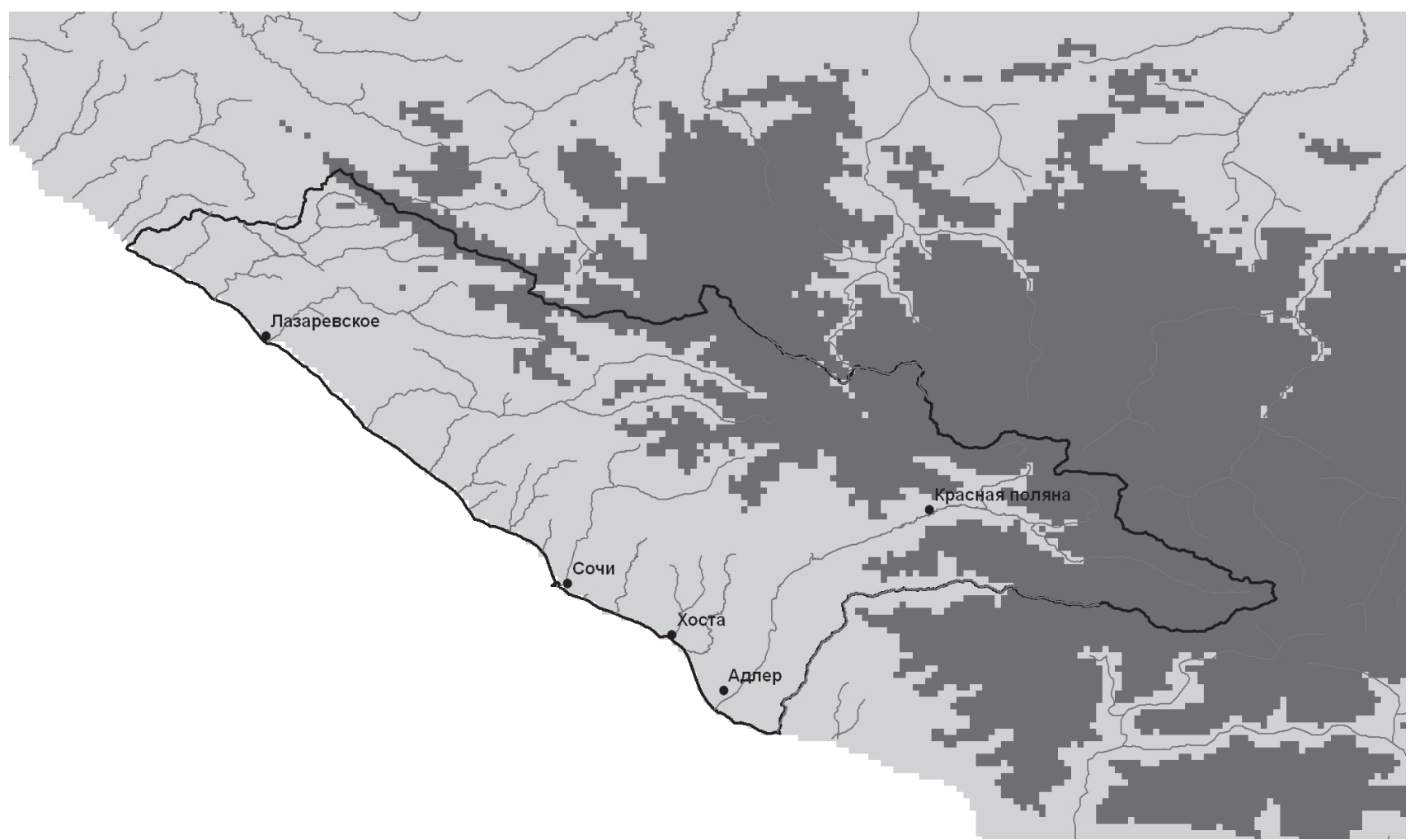

Рис. 1. Результаты прогностического моделирования и дискретной классификации растра, иллюстрирующего пригодность биоклиматических условий для произрастаний айланта высочайшего. Светло-серым цветом изображена пригодная среда обитания, тёмно-серым - не пригодная, чёрная линия - административная граница Большого Сочи 
Под данным рис. 1, биоклиматические условия на $68 \%$ (2383,6 км²) территории Большого Сочи удовлетворяют биологическим требованиям айланта высочайшего, и только на $32 \%$ (1119,7 км²) территории Большого Сочи произрастание этого адвентивного вида невозможно.

К середине XXI в. климатические условия на юге Российского Причерноморья станут еще более благоприятными для распространения большинства адвентивных видов (за исключением экстремального сценария RCP8,5). Так, для айланта по наиболее веро- ятному сценарию RCP4,5 территория, пригодная для его произрастания, к 2050 г. увеличится до 2836,5 км², а к 2070 г. - до 2948,5 км². При самом пессимистичном сценарии (RCP8,5) площадь территории, пригодной для произрастания Ailanthus altissima, будет несколько меньше - 2750,9 км² в 2050-м и 2316,2 км² в 2070 г.

Ряд усредненных биоклиматических и эколого-географических переменных, характеризующих места произрастания некоторых наиболее агрессивных адвентивных видов, приведен в табл. 2 и 3.

Медианные значения биоклиматических переменных для некоторых адвентивных видов

\begin{tabular}{|c|c|c|c|c|c|c|c|c|c|c|c|c|c|c|}
\hline \multirow{2}{*}{ Вид } & \multicolumn{14}{|c|}{ Биоклиматические переменные } \\
\hline & bio1 & bio5 & bio6 & bio8 & bio9 & bio10 & bio11 & bio12 & bio13 & bio14 & bio16 & bio17 & bio18 & bio19 \\
\hline Paspalum dilatatum Poir. & 16,8 & 27,9 & 4,1 & 21,4 & 12,8 & 22,2 & 10,9 & 902 & 120 & 41 & 332 & 140 & 283 & 186 \\
\hline Eleusine indica (L.) Gaertn. & 21,4 & 31,2 & 11,6 & 23,6 & 20,2 & 25,0 & 17,3 & 1300 & 212 & 30 & 549 & 111 & 368 & 169 \\
\hline Ambrosia artemisiifolia $\mathrm{L}$. & 9,8 & 23,9 & $-1,1$ & 16,0 & 5,6 & 17,5 & 2,5 & 753 & 80 & 45 & 222 & 147 & 208 & 173 \\
\hline Robinia pseudoacacia L. & 10,1 & 23,3 & $-0,4$ & 15,2 & 6,2 & 17,2 & 2,9 & 737 & 74 & 47 & 213 & 151 & 199 & 180 \\
\hline Setaria viridis (L.) P. Beauv. & 9,8 & 22,8 & $-1,2$ & 15,5 & 5,6 & 16,9 & 2,4 & 714 & 75 & 44 & 214 & 142 & 199 & 165 \\
\hline Phytolacca americana L. & 11,6 & 27,2 & 0,2 & 16,4 & 7,2 & 20,4 & 3,7 & 794 & 106 & 45 & 296 & 144 & 213 & 177 \\
\hline Duchesnea indica Focke & 11,0 & 24,3 & 0,4 & 11,6 & 6,9 & 18,2 & 3,7 & 755 & 74 & 46 & 216 & 146 & 198 & 165 \\
\hline Conyza canadensis Cronqist & 9,9 & 21,9 & $-0,1$ & 11,0 & 6,0 & 16,7 & 3,2 & 740 & 75 & 45 & 215 & 147 & 198 & 179 \\
\hline Galinsoga ciliata (Raf.) Blake & 9,9 & 22,0 & $-0,4$ & 11,5 & 5,9 & 16,7 & 2,9 & 763 & 75 & 47 & 217 & 153 & 202 & 181 \\
\hline Phalacroloma annuum L. & 9,9 & 23,8 & $-1,5$ & 16,6 & 5,5 & 17,5 & 2,0 & 746 & 77 & 47 & 216 & 150 & 211 & 173 \\
\hline Rosa multiflora Thunb. & 9,6 & 22,8 & $-2,7$ & 15,5 & 4,0 & 17,0 & 1,7 & 931 & 103 & 47 & 290 & 155 & 241 & 180 \\
\hline Paulownia tomentosa Steud. & 12,1 & 28,5 & $-4,6$ & 12,7 & 8,0 & 21,3 & 2,6 & 1359 & 136 & 84 & 376 & 277 & 351 & 310 \\
\hline Commelina communis L. & 12,7 & 29,7 & $-5,2$ & 22,5 & 2,7 & 23,7 & 1,4 & 1366 & 233 & 35 & 599 & 119 & 588 & 130 \\
\hline Elaeagnus pungens Thunb. & 15,6 & 31,7 & $-0,3$ & 24,2 & 11,2 & 25,0 & 5,7 & 1372 & 173 & 71 & 484 & 242 & 465 & 282 \\
\hline Acalypha australis L. & 15,3 & 30,3 & 0,2 & 22,5 & 6,0 & 24,7 & 5,9 & 1563 & 217 & 52 & 581 & 173 & 562 & 174 \\
\hline Trachycarpus fortunei $\mathrm{H}$. Wendl & 14,9 & 30,2 & 0,2 & 22,0 & 5,9 & 24,5 & 5,9 & 1508 & 201 & 52 & 534 & 172 & 491 & 176 \\
\hline Ligustrum japonicum Thunb. & 11,6 & 28,6 & $-3,7$ & 15,4 & 7,2 & 21,2 & 2,8 & 1049 & 109 & 67 & 306 & 215 & 288 & 228 \\
\hline Amorpha fruticosa $\mathrm{L}$. & 12,4 & 31,0 & $-4,8$ & 19,2 & 1,9 & 23,0 & 0,9 & 715 & 106 & 28 & 289 & 96 & 259 & 120 \\
\hline Ailanthus altissima Swingle & 11,6 & 28,6 & $-3,7$ & 15,4 & 7,2 & 21,2 & 2,8 & 1049 & 109 & 67 & 306 & 215 & 288 & 228 \\
\hline
\end{tabular}

Медианные значения эколого-географических переменных для некоторых адвентивных видов

\begin{tabular}{|c|c|c|c|c|c|c|c|c|c|c|}
\hline \multirow{2}{*}{ Вид } & \multicolumn{10}{|c|}{ Эколого-географические переменные } \\
\hline & $\mathbf{w}$ & H & c & pH & alt & slope & built & veg & npp & gdd \\
\hline Paspalum dilatatum Poir. & 88,8 & 0,0 & 6,0 & 6,2 & 135 & 0,9 & 0 & 9 & 0,8 & 4423 \\
\hline Eleusine indica (L.) Gaertn. & 94,6 & 0,0 & 6,2 & 6,2 & 168 & 0,8 & 0 & 8 & 0,7 & 5660 \\
\hline Ambrosia artemisiifolia L. & 97,7 & 0,4 & 6,5 & 6,0 & 88 & 0,5 & 4 & 5 & 0,7 & 1784 \\
\hline Robinia pseudoacacia L. & 94,9 & 0,3 & 5,9 & 6,0 & 94 & 0,5 & 4 & 5 & 0,7 & 1805 \\
\hline Setaria viridis (L.) P. Beauv. & 92,6 & 0,4 & 6,3 & 6,0 & 90 & 0,5 & 3 & 5 & 0,7 & 1772 \\
\hline Phytolacca americana L. & 91,7 & 0,1 & 6,3 & 6,0 & 115 & 0,6 & 4 & 5 & 0,7 & 2283 \\
\hline Duchesnea indica Focke & 94,6 & 0,1 & 5,7 & 6,0 & 78 & 0,7 & 14 & 5 & 0,7 & 2158 \\
\hline Conyza canadensis Cronqist & 93,4 & 0,3 & 6,0 & 6,0 & 47 & 0,3 & 5 & 5 & 0,7 & 1755 \\
\hline Galinsoga ciliata Blake & 99,2 & 0,3 & 6,3 & 6,0 & 42 & 0,3 & 7 & 5 & 0,7 & 1755 \\
\hline Phalacroloma annuum L. & 98,9 & 0,6 & 6,2 & 6,1 & 174 & 0,6 & 2 & 5 & 0,7 & 1853 \\
\hline Rosa multiflora Thunb. & 105,9 & 0,8 & 6,7 & 6,0 & 90 & 0,7 & 5 & 5 & 0,7 & 1770 \\
\hline Paulownia tomentosa Steud. & 124,8 & 1,3 & 4,8 & 5,3 & 648 & 1,8 & 0 & 8 & 0,8 & 2467 \\
\hline Commelina communis L. & 135,3 & 0,5 & 5,4 & 6,1 & 123 & 1,3 & 5 & 8 & 0,8 & 2731 \\
\hline Elaeagnus pungens Thunb. & 113,0 & 0,0 & 5,3 & 5,3 & 108 & 0,6 & 5 & 4 & 0,7 & 3493 \\
\hline Acalypha australis L. & 135,6 & 0,0 & 7,9 & 6,0 & 73 & 0,9 & 8 & 8 & 0,8 & 3191 \\
\hline Trachycarpus fortunei H.Wendl & 135,3 & 0,0 & 8,9 & 6,0 & 57 & 0,9 & 10 & 8 & 0,8 & 3012 \\
\hline Ligustrum japonicum Thunb. & 107,3 & 0,8 & 5,3 & 5,5 & 201 & 0,9 & 4 & 5 & 0,7 & 2427 \\
\hline Amorpha fruticosa $\mathrm{L}$. & 79,5 & 1,4 & 6,1 & 6,5 & 338 & 0,7 & 1 & 9 & 0,6 & 2894 \\
\hline Ailanthus altissima Swingle & 107,3 & 0,8 & 5,3 & 5,5 & 201 & 0,9 & 4 & 5 & 0,7 & 2427 \\
\hline
\end{tabular}

* Примечание: w - влажность почвы мм/м; h - глубина снежного покрова, м; c - содержание органического углерода, кг/м²; аlt - высота над уровнем моря, м; slope - уклон, градусы; built - застроенность территории, \%/км²; veg - принадлежность к биому (1 - тропические вечнозеленые леса, 2 - тропические листопадные леса, 3 - широколиственные вечнозеленые леса умеренного пояса, 4 - хвойные вечнозеленые леса умеренного пояса, 5 - листопадные леса умеренного пояса, 6 - бореальные вечнозеленые леса, 7 - бореальные листопадные леса, 8 - вечнозеленые/листопадные смешанные леса, 9 - саванны, 10 - луга и степи, 11 - местность, покрытая плотной древесно-кустарниковой растительностью, 12 - местность, покрытая разреженной древесно-кустарниковой растительностью, 13 - тундра, 14 - полярные пустыни/ скалы); npp - чистая первичная продуктивность (кг-С/м²/год); gdd - сумма температур вегетационного периода. 
Из приведенных в табл. 2 видов наиболее теплолюбивым видом является Eleusine indica (L.) Gaertn., который легко переносит недостаток осадков в сухое время года. Самыми холодостойкими из наиболее агрессивных чужеродных видов юга Российского Причерноморья являются Commelina communis L. и Amorpha fruticosa L. Последняя, как и Eleusine indica (L.) Gaertn., является самым засухоустойчивым адвентиком.

По данным табл. 3 большинство иноземных видов, натурализовавшихся на юге Российского Причерноморья, приурочено к биому листопадных лесов умеренного пояса.

Из рассматриваемых иноземных видов наименее чувствительна к влажности почвы аморфа кустарниковая (Amorpha fruticosa L.), наиболее - акалифа южная (Acalypha australis L.). Acalypha australis L., как и Trachycarpus fortune (Hook.) H. Wendl, приурочена к почвам, богатым органикой.

Кластерный анализ, проведенный по методу Варда, позволил выделить четыре кластера адвентивных видов.

Первый кластер представлен преимущественно адвентиками Северной Америки и Восточной Азии, принадлежащими к семействам: Poaceae, Fabaceae, Asteraceae (Ambrosia trifida L., Paspalum setaceum Michx., Pueraria lobata (Willd.) Ohwi и др.). Второй кластер образуют в основном чужеродные виды, родиной которых является Северная Америка и Европа. Виды этого кластера представлены большей частью семействами: Asteraceae, Brassicaceae и
Poaceae (Phalacroloma annuum (L.) Dumort., Solidago canadensis L., Solidago gigantea Aiton, Bunias orientalis L. и др.). Третий кластер объединяет иноземные виды, прибывшие из Азии и Южной Америки. Эти виды в основном принадлежат к семействам Poaceae и Asteraceae (Conyzanthus graminifolius (Sprengel) Tamamsch., Eleusine indica (L.) Gaertn., Digitaria violascens Link. и др.). Четвертый кластер представлен преимущественно адвентивными видами Северной Америки и Средиземноморья, принадлежащими к семействам Poaceae, Asteraceae и Cyperaceae (Sorghum halepense (L.) Pers., Cyperus esculentus L., Conyza bonariensis (L.) Cronqist).

Результаты кластеризации, проведенной методом К-средних, приведены на графике средних (рис. 2).

По данным рис. 2 видно, что адвентивные виды кластера 2 приурочены к более богатым почвам. Эти виды способны выносить высокие годовые амплитуды температур, а также низкие температуры в самый холодный месяц года.

Адвентивные виды, принадлежащие к кластеру 2, произрастают преимущественно на равнинных территориях, на небольших высотах над уровнем моря. Кроме того, для мест произрастания особей видов этого кластера характерна наименьшая, по сравнению с другими кластерами видов, средняя годовая температура, средняя температура самой холодной четверти года, средняя суточная амплитуда, а также наименьшая сумма температур вегетационного периода и коэффициент вариации осадков.

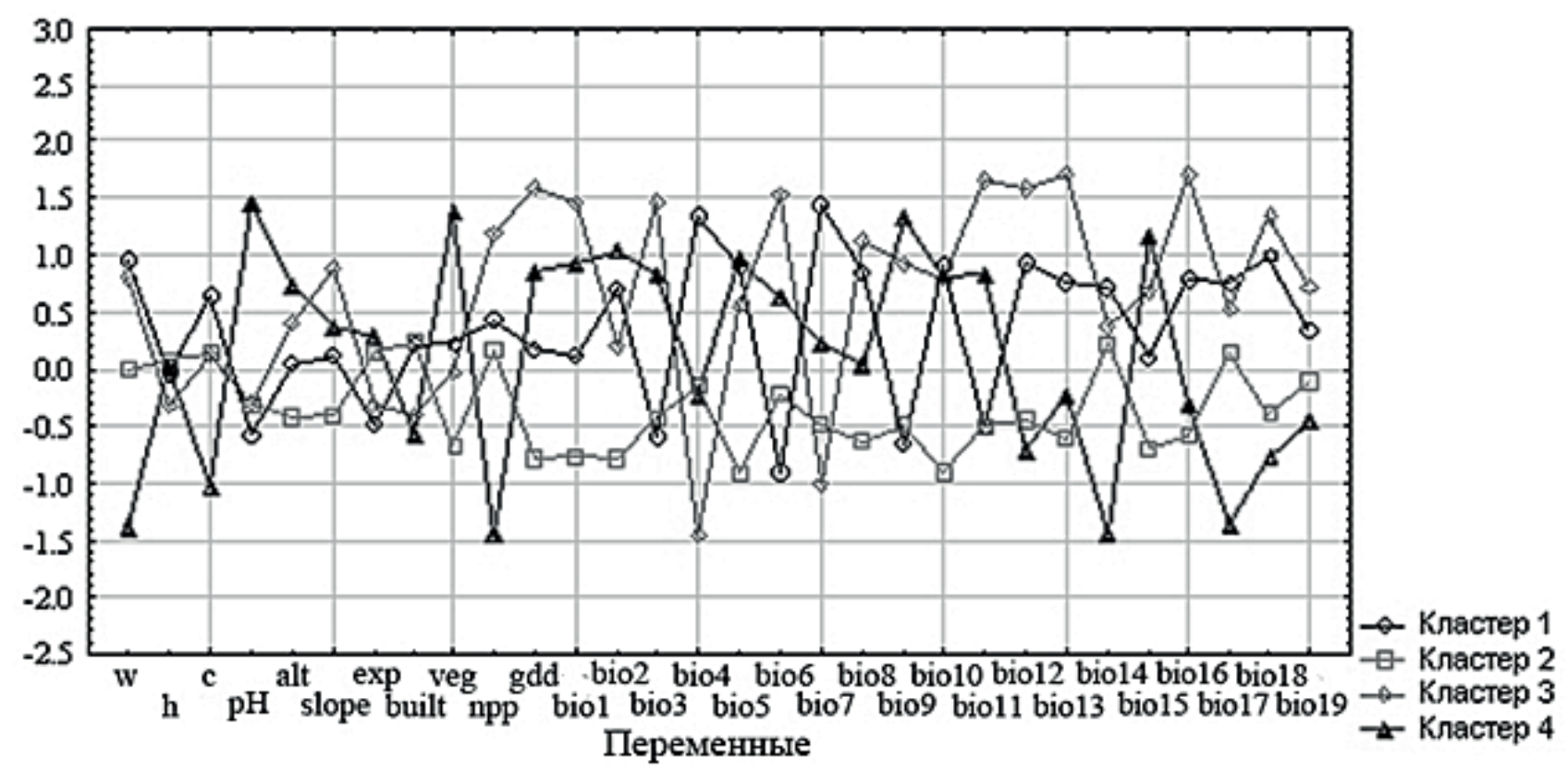

Рис. 2. Результаты кластеризации биоклиматических и эколого-географических переменных методом К-средних. Параметры: w - влажность почвы; h - глубина снежного покрова; с - содержание органического углерода в почве; $\mathrm{pH}$ - pH почвы; alt - высота над уровнем моря; slope - уклон в градуcax; ехр - экспозиция; built - \% застроенной территории; veg - вегетационный потенциал (принадлежность к биому); nрp - чистая первичная продуктивность; gdd - сумма температур вегетационного периода; biol - средняя годовая температура; bio2 - средняя суточная амплитуда температуры за каждый месяц; bio3 - изотермичность; bio4 - стандартное отклонение температур; bio5 - максимальная температура самого теплого месяца; bio6 - минимальная температура самого холодного месяца года; bio7 - годовая амплитуда температуры; bio8 - средняя температура самой влажной четверти года; bio9 - средняя температура самой сухой четверти года; biolo - средняя температура самой теплой четверти года; bioll - средняя температура самой холодной четверти года; bio 12 - годовая сумма осадков; bio 13 - сумма осадков в самом влажном месяце года; bio 14 - сумма осадков в самом сухом месяце года; biol5 - коэффициент вариации осадков; biol6 - сумма осадков во влажной четверти года; biol7 - сумма осадков в сухой четверти года; bio 18 - сумма осадков самой теплой четверти года; biol 9 - сумма осадков самой холодной четверти года 
Иноземные виды третьего кластера зачастую приурочены к территориям со сложным рельефом, для которых характерна относительно высокая средняя годовая температура. Места произрастания видов этого кластера также характеризуются высокой температурой как самого холодного месяца и четверти года, так и всего вегетационного периода, а также самой низкой годовой амплитудой температуры и наибольшей годовой суммой осадков. Экосистемы, в которые внедряются иноземные виды третьего кластера, как правило, имеют высокую чистую продуктивность.

Адвентики четвертого кластера устойчивы к недостатку осадков в засушливый период времени года. Они приурочены к почвам, имеющим наименьшую влажность и плодородность. Для экосистем-акцепторов инвазивных видов этой группы характерна низкая первичная продуктивность.

\section{Заключение}

В ходе проведенных исследований было установлено, что общее количество адвентивных видов, способных внедряться в экосистемы юга Российского При- черноморья, имеющих разную степень нарушенности, составляет 283. Родиной большинства этих видов является Северная и Центральная Америка (88 видов), а также Юго-Восточная Азия и Япония (74 вида). Эти виды характеризуются разнообразными биоклиматическими и эколого-географическими особенностями мест произрастания. Тем не менее, большинство чужеродных видов исторически приурочено к биому листопадных лесов умеренного пояса.

Все адвентики могут быть разделены на четыре кластера, каждый из которых отличается особенностями биоклиматических и эколого-географических параметров.

Биоклиматические условия юга Российского Причерноморья, вплоть до среднегорья, удовлетворяют требованиям подавляющего большинства рассматриваемых адвентивных видов. В будущем территория, благоприятная для произрастания большинства адвентиков, за исключением самого экстремального сценария климатических изменений, будет только лишь увеличиваться. В перспективе также следует ожидать увеличения видового пула адвентивных видов на юге Российского Причерноморья.

\section{Литература}

1. Акатов В.В., Акатова Т.В., Шадже А.Е. Видовое богатство древесного и кустарникового ярусов прирусловых лесов Западного Кавказа с доминированием иноземных видов // Экология. 2012. - № 4. - C. 276-283.

2. Антонова Л.А. Инвазионный компонент флоры Хабаровского края // Российский журн. биологических инвазий. - 2012. - № 4. - С. 2-9.

3. Василевич В.И. Доминанты в растительном покрове // Бот. журн. - 1991. - Т. 76. - С. 1674-1681.

4. Виноградова Ю.К. Экспериментальное изучение растительных инвазий (на примере рода Bisens) // Проблемы изучения адвентивной и синантропной флоры в регионах СНГ. - М. : Ботанический сад МГУ, 2003. - С. 31-33.

5. Второй оценочный доклад Росгидромета об изменениях климата и их последствиях на территории Российской Федерации. - М. : Росгидромет, 2014. - $61 \mathrm{c}$.

6. Егошин A.B. Моделирование пространственного распределения видов на территориях ООПТ Западного Кавказа с использованием геоинформационных систем // Биоразнообразие государственного природного заповедника «Утриш». Научные труды. Том 1. - 2013. - С. 35-43.

7. Зернов А.С. Иллюстрированная флора юга Российского Причерноморья. - М. : Товарищество научных изданий КМК, 2013. - 588 с.

8. Маренчук Ю.А. Адвентивный элемент флоры Центрального Предкавказья // Фундаментальные исследования. - 2009. - № 3. - С. 50-51.

9. Серегин А.П., Шведчикова Н.К. Дополнения к флоре Северо-Западного Кавказа // Бюлл. МОИП. Отд. биол. - 2009. - Т. 114, вып. 3. - С. 62-63.
10. Тимухин И.Н. Флора сосудистых растений Сочинского национального парка // Инвентаризация основных таксономических групп и сообществ, созологические исследования Сочинского национального парка - первые итоги первого в России национального парка. - М. : Престиж, 2006. - C. 41-84.

11. Elton C.S. The ecology of invasions by animals and plants. - London : Methuen, 1958. - 181 p.

12. Forman R.T., Deblinger R.D. The ecological road-effect zone of a Massachusetts (USA) suburban highway // Conservation Biology. - 2000. - Vol. 14. P. 36-46.

13. Gelbard J.L., Belnap J. Roads as conduits for exotic plant invasions in a semiarid landscape // Conservation Biology. - 2003. - Vol. 17. - P. 420-432.

14. Goodman D. Theory of diversity-stability relationships in ecology // Quart. Rev. Biol. - 1975. Vol. 50. - P. 237-266.

15. Green P. T., Lake P.S., O'Dowd D.J. Resistance of island rainforest to invasion by alien plants: influence of microhabitat and herbivory on seedling performance // Biological Invasions. - 2004. - Vol. 6. - P. 1-9.

16. Hobbs R.J., Huenneke L.F. Disturbance, diversity, and invasion: implications for conservation // Conservation Biology. - 1992. - Vol. 6. - P. 324-337.

17. Holway D.A. Distribution of the Argentine ant (Linepithema humile) in northern California // Conservation Biology. - 1995. - Vol. 9. - P. 1634-1637.

18. Jesson L.D. Kelly, Sparrow A. The importance of dispersal, disturbance, and competition for exotic plant invasions in Arthur's Pass National Park, New Zealand // New Zealand J. Botany. - 2000. Vol. 38. - P. 451-468. 
19. Kennard D.K., Gould K., Putz F.E., Fredericksen T.S., Morales $F$. Effect of disturbance intensity on regeneration mechanisms in a tropical dry forest // Forest Ecol. Management. - 2002. - Vol. 162. - P. 197-208.

20. May R.M. Will a large complex system be stable // Nature. - 1972. - Vol. 238. - P. 413-414.

21. Parker I.M., Mertens S.K., Schemske D.W. Distribution of 7 native and 2 exotic plants in a tallgrass prairie in southeastern Wisconsin: the importance of human disturbance // Amer. Midland Naturalist. - 1993. - Vol. 130. P. 43-55.

22. Pimm S.L. Structure of food webs // Theor. Popul. Biol. 1979. - Vol. 16. - P. 144-158.
23. Rejmanek $M$. A theory of seed plant invasiveness: the first sketch // Biological Conservation. - 1996. - Vol. 78. P. $171-181$.

24. Rejmanek M., Richardson D.M., Pysek P. Plant invasions and invisibility of plant communities // Vegetation Ecology / Ed.: van der Maarel. - Oxford : Blackwell, 2005. - P. 332-355.

25. Simberloff $D$. Invasion biology. Critique of a pseudoscience // Ecological Economics. - 2004. - Vol. 48. P. 360-362.

26. Vila M., Pujadas J. Land-use and socio-economic correlates of plant invasions in European and North African countries // Biological Conservation. - 2001. - Vol. 100. P. 397-401.

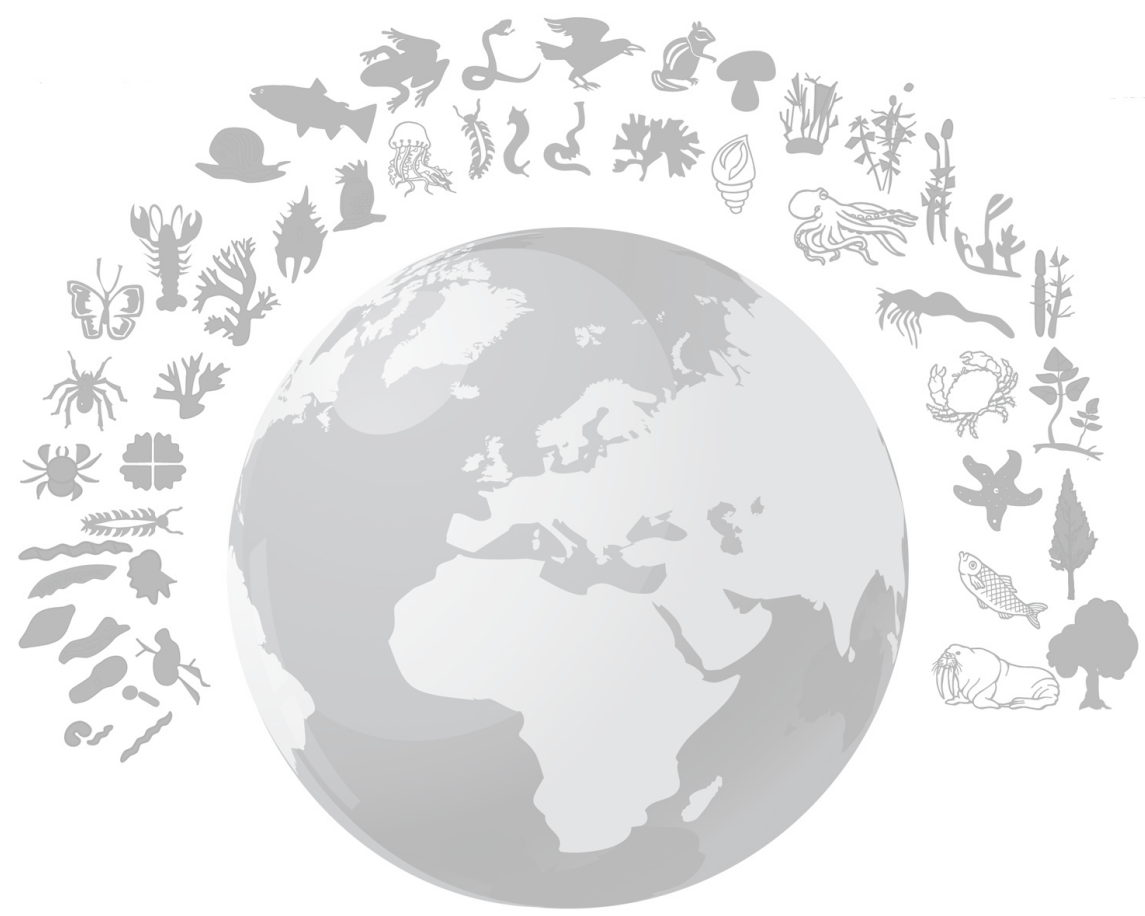

